\title{
Neoliberalization, uneven development, and Brexit: further reflections on the organic crisis of the British state and society
}

\section{Bob Jessop}

To cite this article: Bob Jessop (2018): Neoliberalization, uneven development, and Brexit: further reflections on the organic crisis of the British state and society, European Planning Studies, DOI: 10.1080/09654313.2018.1501469

To link to this article: https://doi.org/10.1080/09654313.2018.1501469

\section{а}

(c) 2018 The Author(s). Published by Informa

UK Limited, trading as Taylor \& Francis Group

巴n Published online: 19 Jul 2018.

Submit your article to this journal

View Crossmark data $\complement$ 


\title{
Neoliberalization, uneven development, and Brexit: further reflections on the organic crisis of the British state and society
}

\author{
Bob Jessop \\ Department of Sociology, Lancaster University, Lancaster, UK
}

\begin{abstract}
Neoliberalization is a variegated series of processes with a core policy set that comprises: liberalization, deregulation, privatization, recommodification, internationalization, reductions in direct taxation, and decriminalization of predatory economic activities. Compared to the era of Atlantic Fordism and Spatial Keynesianism, neoliberalization promotes uneven development in the name of competitiveness and pursues policies that largely neglect its adverse economic, social, and political repercussions. Growing inequalities of income, wealth and life-chances have been ascending the political risk agenda and, through works such as Piketty's Capital in the twenty-first Century, have been 'conversationalized'. Yet little concrete action occurs to remedy the results of uneven development in societies undergoing neoliberal regime shifts. This contribution relates these issues to Brexit as a symptom of the organic crisis of British society, marked by manifold economic, political and social crises, and the continuing failure to address uneven development. The referendum question falsely posited that Brexiting would resolve many of these problems. However, the real issue should have been 'in' or 'out' of neoliberalism. Failure to deliver the anticipated benefits of Brexit will interact with the continuing crisis of British society to reinforce environmental, economic, social, and political crises and provide further grounds for right-wing populist mobilization.
\end{abstract}

\author{
ARTICLE HISTORY \\ Received 11 July 2018 \\ Accepted 12 July 2018

\section{KEYWORDS} \\ Organic crisis; Brexit; \\ financialization; \\ neoliberalization; uneven \\ development; populism
}

\section{Introduction}

My contribution explores the genealogy and development of neoliberalism in its AngloSaxon and European heartlands and relates it to the recent changes in the world market, the world of states and a still emerging global society. As is common nowadays, I examine neoliberalization as a variegated, partial and hybridized process (cf. Peck \& Theodore, 2012). I elaborate this approach in two main ways: the first is to present a taxonomy of neoliberalization; the second is to outline a periodization of one taxon, namely, principled neoliberal regime shifts in their Anglo-Saxon heartland. The best-known and most-studied cases of such shifts are the United States of America and United Kingdom; several others exist, including, most egregiously, Iceland. Next, I suggest that 
neoliberalization is a major driving force of uneven development. Indeed, it is a feature, not a bug, of the neoliberal project. I examine this within a multi-temporal, multispatial analytical framework. There is an interesting contrast with Ordoliberalism. For, whereas neoliberalization promotes disruption to boost competition and competitiveness, Ordoliberalism seeks to achieve these goals by establishing a stable institutional framework. This contrast is reflected in the greater propensity of neoliberal regime shifts to crisis-tendencies, 'blowback' effects, and resistance. I illustrate this from the Brexit process, but other cases are the rise of US populism and the actions (and inactions) of the Trump Presidency. I conclude with some comments on the likely consequences of Brexit for the ongoing crisis in Britain's economy, state, and society.

\section{Neoliberalism and neoliberalization}

Given the polyvalence of the core terms, we find diverse typologies of neoliberalism and/or neoliberalization. None is the best entry-point for all theoretical and practical purposes. For this anniversary issue of European Planning Studies, I begin with its economic and political dimensions rather than its pre-history or other salient aspects of neoliberalism. From this perspective, neoliberalization is an economic, political, and social project that tends to judge economic activities in terms of profitability and social activities in terms of their contribution to accumulation and seeks to promote this vision through institutional redesign, encouraging new forms of subjectivity and conduct, and establishing new spatio-temporal fixes. This interpretation might suggest that it promotes the spontaneous operation of market forces. However, neoliberalization actually depends on the exercise of political power to establish and consolidate its various forms and, when confronted with crisis, to rescue them. As such it involves all three of Max Weber's types of 'political capitalism': unusual deals with political authority, accumulation through force and domination, and predatory economic activities (Weber, 2009). Thus one might argue that it entails a primacy of the political (understood here to include the polity, politics, and policy) rather than free market as envisaged in 'theoclassical' economics. The argument below builds on this analysis.

Based on theoretical considerations and historical observation, four main forms of neoliberalism can be distinguished analytically. These may exist in hybrid forms and, depending on their contradictory and crisis-prone evolution, different forms may also succeed each other in the same economic and political space. ${ }^{1}$

First, the most radical form was neoliberal system transformation in post-Soviet successor states. Russia and Poland provide two contrasting cases: Chicagoan 'creative destruction' induced by neoliberal shock therapy and a more Ordoliberal 'market therapy without shock'.

Second come neoliberal regime shifts. Breaking on principle with post-war Atlantic Fordist class compromise, at least six neoliberal policies were pursued in order to modify the balance of forces in favour of capital. These policies comprise: (1) liberalization to promote free market competition or at least greater market competition to the detriment of monopoly or state monopoly competition; (2) deregulation, based on a belief in the efficient market hypothesis and the prudential, self-preserving instincts of companies and financial institutions; (3) privatization to roll back the frontiers of the polity in favour of the profit-oriented, market-mediated economy and the efficient allocation of 
resources and dynamic innovative potential that markets are expected to deliver; (4) the introduction of market proxies in the residual state sector to favour efficient, effective, and economical delivery of public services, thereby reducing the scope for non-market logics in the public sector, especially when combined with cuts in state budgets; (5) reductions in direct taxation on corporate income, personal wealth, and personal income - especially on (allegedly) entrepreneurial income - in order to boost incentives for economic agents to earn, save, invest, innovate, create, and accumulate individual and corporate wealth rather than have the state determine the level and content of the national output; and (6) the promotion of internationalization to boost the free flow of goods and services, profit-producing investment and technology transfer, and the mobility of interest-bearing capital, all with a view to completing the world market. One might add to this list the decriminalization of financial crime (Black, 2014). Thatcherism and Reaganism are well-known cases but similar shifts occurred in Australia, Canada, Cyprus, Eire, Iceland, and New Zealand. While often identified with right-wing parties, these shifts have also been initiated, maintained or backed by centre-left parties, sometimes under a 'Third Way' label.

Type three comprises economic restructuring and regime shifts that occurred in response to inflationary and/or debt crises in economies pursuing import-substitution growth. These changes were imposed from outside by transnational economic institutions and organizations backed by leading capitalist powers and backed by partners among domestic political and economic elites in the countries affected. Neoliberal reforms were a condition for financial and other aid to crisis-ridden economies in parts of Africa, Asia, Eastern and Central Europe, and Latin America. While the second and third types often pursue similar policies in the (semi-)periphery of the global economy, they have analytically distinct roots.

Fourth, we observe a more pragmatic, partial, and potentially reversible set of neoliberal policy adjustments. Not all of the six (or seven) neoliberal economic policies are adopted in such cases because this type involves more modest and piecemeal changes deemed necessary by governing elites and their social base(s) to maintain existing economic and social models in the face of specific crisis-tendencies and the challenges generated by growing world market integration. In Europe, the Nordic social democracies and Rhenish capitalism provide examples. However, such adjustments can cumulate despite the fluctuating political fortunes of the parties that back them and, as if by stealth, lead to neoliberal regimes (witness Germany in the last 25 years). Moreover, following the North Atlantic Financial Crisis (hereafter, NAFC) and the Eurozone crisis, these cumulative changes have become harder to reverse as global pressures and the approach to crisismanagement in Europe tend to reinforce neoliberalization. This can be seen in efforts to institutionalize neoliberalism in a succession of pacts and crisis-management responses in the Eurozone economies. One response is the rise of nationalist and populist blowback in core and periphery alike.

\section{Periodization of neoliberal regime shifts}

Neoliberalization in its Anglo-Saxon heartlands has involved seven main stages to date. The first is its pre-history as an intellectual, ideological and political movement up to 'the point of no return', i.e. when the momentum behind a neoliberal regime shift 
made it highly likely that a political party committed to neoliberal policies would enter office with a popular mandate or through negotiations with other parties to form a coalition government. Stage two sees the formation of a government committed to a neoliberal agenda and efforts to consolidate control over the legislature and executive branch in the face of opposition inside the government itself or from other forces acting within or at a distance from the state. Consolidation initially focused on shifting the balance of forces through a mix of short-term concessions, passive revolution, and concerted efforts to win hegemony or, in extremis, use of police powers to overcome resistance. This process may overlap with the third stage, namely, attempts to roll back the institutions and institutionalized compromises associated with different versions of the Atlantic Fordist post-war settlement. A key aim of stages two and three was to translate the discursive politics of free markets and a liberal state into substantive policy initiatives to remove obstacles to the neoliberal project. Fourth come efforts to roll forward neoliberal institutions, consolidate the shift in the balance of forces, and constitutionalize neoliberal principles nationally and, where possible, regionally and globally - making them harder to reverse even were the political conjuncture to turn temporarily against continued neoliberalization.

The fifth stage was blowback as an unintended but inevitable effect of a one-sided emphasis on serving mobile export-oriented profit-producing capital and interestbearing capital. This led to resistance from disadvantaged capitals, intensified uneven development, increasing inequalities of income and wealth, debt-default-deflation dynamics (cf. Rasmus, 2010), and resistance from subaltern groups. This is the moment of the 'Third Way' and analogous attempts to provide flanking and supporting mechanisms to maintain the momentum of neoliberal regime shifts.

Stage six was initiated by the irruption of the NAFC. This initially signified a crisis of finance-dominated accumulation regimes but did not produce a crisis of neoliberalism in the US and UK. Indeed, this only occurred in Iceland, where the weight of the hypertrophied financial sector far exceeded that in the UK and radical measures imposed the costs of crisis-management on financial capital (Cyprus's implosion came later as part of the Eurozone crisis). However, in the first two cases, while financial capital may have lost some credibility, it continued to dominate the accumulation regime, the state apparatus, and, in the USA, the legislature. It could therefore exploit the crisis, ensuring that it did not, in Rahm Emanuel's words, 'go to waste'. Indeed, central banks and states in the neoliberal heartlands intervened massively to rescue imprudent and predatory banks that were deemed too systemically important or too well-connected politically to be allowed to fail. Toxic assets and losses were socialized at the expense of households, the public debt, and industrial capital. Financial crisis was translated discursively and practically into public debt and fiscal crises and intensified neoliberal vilification of state spending, with calls for further austerity measures.

Stage seven emerged in the context of the sixth stage. Thanks to its dominance in the power bloc, financial capital was able to manoeuvre to delay, dilute, and otherwise weaken attempts to re-regulate its operations at the expense of the public purse and future crises. This created the conditions to transform a crisis of finance-dominated accumulation into a crisis in this accumulation regime. At the same time, efforts continued to transform neoliberal austerity policies and politics into a permanent, constitutionalized state of austerity that undermine the institutions and practices of liberal democracy (Bruff, 2014; Jessop, 2016b, 2018). These are partly aimed at limiting and defeating resistance to neoliberalism 
and its effects. This resistance has taken increasingly vocal populist forms marked by strong exclusionary discourses, practices, and effects. These measures and the new forms of resistance indicate the continuing primacy of politics in neoliberalization.

\section{The economic significance of neoliberalization}

Neoliberalization promotes ever more forcefully (and, in many cases, forcibly) the completion of the world market and the correlative, but increasingly contradictory, subordination of all social relations to the competitive logic of capital accumulation. Rhetorically, its proponents aim to overcome the frictions of national boundaries, open national economies to foreign competition, intensify the global division of labour, and enhance the role of mobile financial capital in equalizing profit rates on a global scale and, indeed, equalizing the return on all commodified assets. Ever more rarefied forms of fictitious capital (including derivatives) are crucial vectors of this process. While the goal of completing the world market seems to privilege market forces its advancement, consolidation, crisis-management, and defence against resistance depend on the primacy of the political. Substantively, neoliberalization privileges some capitals and spaces over others, enabling them to appropriate superprofits at the expense of less powerful economic agents and less attractive spaces. Among other effects, world market integration in the shadow of neoliberalism enhances capital's capacity to defer and/or displace the effects of its internal contradictions by increasing the global scope of its operations, reinforcing its capacities to disembed certain of its operations from local material, social, and spatio-temporal constraints, enabling it to deepen the spatial and scalar divisions of labour, thereby expanding opportunities to relocate across spaces and places and move up, down, and across scales. It also collapses time horizons by commodifying and securitizing the future. All of these processes have their specific contradictions and crisis-tendencies.

To establish why neoliberal regime shifts, cumulative neoliberal policy adjustments, and the politics of neoliberalization prove resilient rather than retreat in the face of their respective crisis-tendencies, we must look beyond their intellectual appeal and domestic and international political backing to the economic logic of neoliberalization. This is related to the distinction between the use-value and exchange-value aspects of the elementary form of value, namely, the commodity. The commodity is both a use-value and an exchange-value: without use-value, it would not be purchased; without exchange-value, it would not be produced. Analogous properties are found in other forms of the capital relation. The worker is both a concrete individual with specific skills, knowledge, and creativity and an abstract unit of labour power substitutable by other such units (or, indeed, other factors of production); the wage (including the social wage) is both a source of demand and a cost of production; money functions both as a 'national' currency circulating within a monetary bloc where it is subject to state control and as an international money exchangeable against other monies in currency markets; profit-producing capital is a more or less concrete stock of time- and place-specific assets undergoing valorization according to their specific properties and abstract value in motion (notably as realized profits available for re-investment); land, defined to include all natural resources, is a free gift of nature and a monopolistic claim on revenues in the form of rent; knowledge circulates as part of the intellectual commons and can also become the object of intellectual property rights; and so forth. 
In each case, neoliberalization privileges the exchange-value aspect over the use-value aspect of a given form of the capital relation. It emphasizes cost reduction and cost recovery and subjects all economic activities to profit-oriented logic regardless of any negative externalities. This structural privileging of exchange- over use-value not only favours capital over labour but also benefits hypermobile profit-producing and interest-bearing capital at the expense of other capitals that are embedded in broader sets of social relations and/or that must be valorized in particular times and places. Mobile profit-producing capital gains to the extent that it can plausibly threaten to reorganize its production chains to avoid barriers to differential accumulation that arise from state intervention and/or pressure from subaltern classes and social movements. This intensifies the influence of the logic of capital on a global scale as the global operation of the law of value commensurates local conditions at the same time as it promotes the treadmill search for superprofits that exceed the prevailing world market average rate of profit. The same phenomenon can be seen at smaller scales, such as the European Union, where a combination of enlargement and increased integration inside the single market enabled European and, even more, non-European capital to exploit national, regional, and local differences and demand fiscal, financial, or material concessions to attract investment. In turn, interest-bearing capital is the most abstract and general expression of exchange-value not only in the capitalist mode of production itself but also in capitalist social formations more generally. It gains from the full set of neoliberal policies (including de-criminalization) which facilitate, inter alia, financial innovation (e.g. securitization), unregulated speculation, and predatory finance. In this sense, compared to the largely intermediary roles of finance in Fordist regimes and, likewise, in the much-heralded (if somewhat lagging or lacking) productivist, post-Fordist knowledge-based economy $(\mathrm{KBE})$, neoliberalization promotes not a benign form of finance-led growth but a predatory finance-dominated accumulation regime.

Such one-sided treatment can overlook or deny, but not suppress, the significance of the use-value aspects of the above-mentioned forms of the capital relation. Eventually their vital role in capitalist (and societal) reproduction becomes evident and, absent appropriate ways to handle the contradictions between use- and exchange-value, crises emerge that may forcibly re-impose the unity of the capital relation, typically through a more or less sudden and destructive process of devalorization. This one-sided treatment also increases inequalities of wealth and income that undermine demand and also generate growing popular resistance - issues recognized in largely neoliberal spaces such as the World Economic Forum as major threats to prosperity, social cohesion, and political stability and 'mainstreamed' by texts like Piketty (2014). But neither crises nor elite handwringing can easily reverse or otherwise redress the structural impact of neoliberal measures since the 1980s and their juridico-political consolidation through neoliberal constitutionalism and authoritarianism. This would require a favourable balance of forces and concerted action in a period when mainstream opposition parties and movements have been weakened and further demobilized by the neoliberal mantra of 'no alternative'. This has created the space for extreme populist blowback against neoliberalization.

\section{Neoliberalization and uneven development}

Uneven development occurs in all modes of production and social formations but assumes different forms in each. In capitalism, it is shaped by a distinctive political economy of 
time, by disjunctions among labour time, production time, circulation time, turnover time, and naturally necessary reproduction time within and across different sectors, and by the dialectic of time-space compression and distantiation. While the world market as both the presupposition and posit of capital accumulation is the final frontier and ultimate horizon of uneven development, the latter is better seen as a series of fractal processes that occur in self-similar but not identical ways, cross-cutting and interweaving territories, places, scales, and networks and producing complex multi-spatial and multi-temporal effects (cf. Jessop, 2016a).

Together these economic and extra-economic mechanisms provide conditions for uneven production of absolute and relative-surplus value and its redistribution in form of superprofits and quasi-rents tied to spatial and/or political advantages (Hadjimichalis, 1987, 2018). Institutional and spatio-temporal fixes shape the forms and effects of uneven development, including the scope for combined development. But structural effects and strategic interventions are mediated in complex, ultimately uncontrollable, ways by inherited institutions, competing strategies, the shifting balance of forces, and creative destruction. This emphasizes, as Hudson notes, 'the decisive role of distinctive subnational couplings of economic structures and modes of governance and regulation' (Hudson, 2003, p. 50).

The pattern of uneven development varies with the differential articulation of economic, political and social spaces into a variegated world market. For example, there is a significant contrast between the heartlands of Atlantic Fordism in its heyday and today's neoliberal heartlands regarding strategies and policies towards uneven development. Atlantic Fordism was associated with measures to limit and/or compensate for uneven development (e.g. through spatial Keynesianism, cf. Brenner, 2004). The political and policy focus in this period was on creating the conditions for a Fordist dynamic (with significant variation among economies in the circuits of Atlantic Fordism), integrating national economic space, generalizing norms of mass consumption, and spreading the benefits of Fordist growth through infrastructural investment, collective bargaining, collective consumption, and welfare state measures. This required measures to compensate for the uneven sectoral, regional and social impact of post-war growth to promote the virtuous cycle of Fordist accumulation. In contrast, the rise and consolidation of neoliberal regimes was marked by neglect of uneven development and/or measures to reinforce it by actively freeing market forces. These measures involved rolling back policies and apparatuses concerned to counteract uneven development and rolling forward policies and reorganizing apparatuses to support sectoral and regional winners rather than to sustain losers or compensate sectors or regions that lose from the new neoliberal strategy. Two related aspects of this approach are: identify cities and regions that can serve as national (or EUwide) champions; and induce, persuade or force declining regions to compete on neoliberal criteria for limited funds that might facilitate regeneration. Both aspects intensify uneven development, especially when declining regions are blamed for their own decline, required to make themselves attractive to capital based on mobilizing their own resources, or left to rot. More generally, whether promoting strong competition based on dynamic efficiency or weak competition based on a race-to-the bottom, global, European, national, regional, and local competitiveness took precedence over inter-regional and societal cohesion. This is because the neoliberal policy set prioritizes exchangevalue and the rights of capital over hard-won economic, juridico-political and social 
rights for workers and citizens or a broader sense of national solidarity. Its destructive impact is reinforced by accumulation through dispossession (especially the plundering of public assets and the intellectual commons to benefit capital), regulatory arbitrage, and the limited mobility of productive capitals that have to be valorized in particular times and places.

\section{Uneven development in the United Kingdom}

Neoliberal measures since 1979 reinforced the ongoing pattern of de-industrialization and, where core industries survived, contributed to their balkanization, i.e. their splitting up among rival foreign capitalist interests. Successive governments have declared Britain to be 'open for business' (and takeover), leading to competing and uncoordinated ties to foreign capital, including, recently, Chinese, Indian, and Russian interests alongside 'the usual suspects'. Without the economic, political, and social bases for a concerted national economic strategy, Britain's economic fortunes came to depend heavily on the vagaries of finance-dominated accumulation and the wider world market and a low-skill, low-tech, low-wage, and even zero-hour service sector associated with a neoliberal race to the bottom. The combined impact of general macro-economic policies and specific microeconomic measures to restructure nationalized industries (which were over-represented in the 'north') plus government investment projects that have favoured London and the Rest of the South-East ${ }^{2}$ have regional implications. It has benefitted the City of London, and rentier and producer service interests located in London and the South-East (Martin, 1988; Martin, Pike, Tyler \& Gardiner, 2015; Peck \& Tickell, 1992) plus mobile transnational capital, and high-tech industries. Marginal and poor localities in dynamic core cities, notably London, and regions have gained from their ties to the dynamic and internationalized core. Regions and third-tier cities and towns outside London and the Rest of the South East, especially where the decline or closure of traditional industries has not been countered by the rise of new sectors and where public services have suffered from withdrawn subsidies and other neoliberal austerity measures. Overall, this has generated far more job losses in manufacturing (both in absolute and relative terms) in the 'north' of England and the provinces than in the 'south'. The resulting divergent set of regional economies with marked differences in economic structure, sectoral composition and trade performance continues to constrain efforts to 'take back control' of the British economy.

These problems are aggravated by the historical weakness of the British state and its inability to pursue a serious economic strategy consistently and effectively. Post-war growth in other advanced economies had been secured with more or less good results in dirigiste regimes, corporatist regimes, and liberal regimes (Shonfield, 1965). However, the British state (understood in Gramscian terms as 'political society + civil society') $)^{3}$ lacked the capacities to engage in statist intervention, effective corporatist coordination, or a consistently rigorous laissez-faire line. Its interventions therefore oscillated uneasily among the three strategies that all failed in their different ways in different conjunctures, thereby reproducing Britain's 'flawed Fordist' mode of growth (Jessop, 1980, 1992; Jessop, Bonnett, Bromley, \& Ling, 1988). A weak state meant that efforts to promote re-industrialization, develop a competitive service sector, and modernize the wider society failed. In contrast, de facto or principled laissez-faire has enabled the City to thrive in a deregulated and international environment. 
Indeed, while key aspects of the post-war social democratic and Conservative 'One Nation' post-war settlement have been rolled back, neoliberal policies have not provided the basis for a new national accumulation strategy or stable 'popular capitalist' social basis. Instead neoliberalization has promoted the deeper integration of (parts of) British economic space into the circuits of international financial capital and advantaged international profit-producing capital. The ever more visible polarization of wealth and income, the intensified pattern of uneven development, and the shift from a welfare to a workfare state are generating discontent (reflected most recently in the Brexit referendum). This in turn prompts measures to monitor the population, insulate government from popular demands for economic and social justice, encourage divide-and-rule tactics, and, whenever necessary, repress dissent.

\section{Historical context and conjunctural shifts}

While financialization in the UK has been boosted by neoliberalization, it has deep historical roots. This reflects the City of London's distinctive role as the leading international financial centre for international financial transactions. Financial capital (in the interconnected forms of money-dealing capital, stock-dealing capital, and interest-bearing capital) has long been dominant in the British power bloc (cf. Ingham, 1984). This is reflected in the dominance of neoliberal policy paradigms at different sites in the state apparatus and political regime. While the City of London has changed, with domestic banks and financial institutions ceding primacy to international financial institutions and with interestbearing capital becoming more important than commercial capital, the City remains a key force in the power bloc and key factor in uneven development. It has gained influence due to financial innovation, increasing its leverage, and thanks to its massive internationalization. This weakens the ties between the interests of leading sections of the British power bloc (if, indeed, one can still talk of a British power bloc) and the development of British economic space as a whole. It has also weakened the ties between the power bloc and British working class, reinforced by the decline of traditional heavy industry, retail capital, and small and medium enterprises, all of which lack the capacity to challenge the hegemony of financial capital.

The growing split within the Establishment and wider society since the 1950s concerns the UK's relationship to Continental Europe and the EU and the alternatives such as Atlanticism, globalism, and protectionism. There is also a crisis of authority rooted in the decline of deference, loss of confidence among the ruling classes, and recurrent state failure. The recent legitimacy crisis results from the failure of successive neoliberal projects, pursued under Conservative, New Labour, and coalition governments alike, to deliver sustainable nationwide prosperity. The representational crisis is evident in a growing disconnection between the natural governing parties in Westminster, party members, and their voters. This created the space for the rise of left and right populism, for Corbynism as a social movement opposed to the Blairite rump of MPs who control the parliamentary party, and, of course, for the disaffection shown in the Brexit vote. The legitimacy and representational crises were exacerbated by the loss of control over public opinion, which is the hinge between political and civil society, over continued EU membership. This was due in part to the hostility of much of the British press. Finally, there is a wider organic crisis in the social order, reflected in contestation over 
'British values', disputed national and regional identities, north-south and other regional divides, the metropolitan orientation of intellectual strata, and generational splits.

Overall, the combination of weak state capacities in the period of flawed post-war economic expansion and the subsequent pursuit of neoliberal strategies has produced a seriously weakened 'real economy' and hypertrophied rent-seeking financial sector. Thus, successive governments have failed to provide adequate technical and vocational training to address labour shortages, to protect worker and union rights to limit the race to the bottom and spur productivity-boosting capital investment, to encourage $\mathrm{R} \& \mathrm{D}$ to promote the knowledge-based economy, to overcome the housing crisis and reduce the unproductive 'housing sector borrowing requirement', to fund the National Health Service rather than sustain the military-industrial complex or reduce corporate and top-rate taxes, and to moderate uneven regional development. After the irruption of the NAFC, New Labour responded with measures to bail out the financial sector and, as a result, transformed a financial crisis into a fiscal crisis marked by rising public sector deficits, which were ruthlessly exploited by the Conservative Party, City of London, and right-wing press to discredit New Labour's hard-won reputation for economic competence. Cameron built on this economic, political, and intellectual failure to pursue a harder neoliberal line. And, despite her initial rhetorical critiques of the economic and social injustices of past policies, repeated on the steps of 10 Downing Street on becoming Prime Minister, the austerity state is surviving under Mrs May's premiership and the new Chancellor (Philip Hammond) is committed to further austerity to build reserves against possible economic and fisco-financial problems during the negotiations or following Brexit.

\section{Financialization, Thatcherism, New Labour, and neoliberalism}

A 1989 report in the Bank of England's Quarterly Bulletin questioned the benefits of London's role as an international financial centre. It noted:

There may of course be disadvantages in hosting a major financial centre. Salaries and wages may be forced up, thus driving up rents and house prices, with undesirable social consequences. Regional disparities may be exacerbated and the congestion of local transport systems may be aggravated. The economy may face risks due to over-dependence on a single sector. The operation of monetary policy may become complicated by the need to nurture the financial sector. Regulation may need to be more complex than otherwise. Finally, it has sometimes been argued that the financial sector merely preys on the rest of the economy, adding to costs and distorting other markets - by, for instance, attracting able individuals who might be more socially productive in other areas such as manufacturing (Davis \& Latter, 1989, p. 516).

Having noted this danger, the authors quickly responded that, 'on balance, the financial sector may be judged to offer substantial net benefits to the economy' (ibid.).Yet these worries were well-founded. Indeed, the feared tendencies have intensified in the last three decades and entrenched the UK economy's dependence on international finance. Uneven development has been reinforced to the benefit of London and the detriment of other regions. In short, the problems that became evident in the financial crisis in 2007-8 and continuing economic decline did not emerge out of the blue. The City of London has seen increasing internationalization and ever-closer integration into the 
global circuit of capital. Regulatory arbitrage played a key role here, when, following the 'Big Bang' that liberalized and deregulated financial capital, London could become the leading international centre for international financial capital. Indeed, it is noteworthy that many of the biggest financial scandals that have transpired in 2007-2018 were generated through activities in the City, regardless of the nationality or primary seat of the financial institutions involved.

Moreover, by privileging owner occupation in the hope of electoral benefit, successive governments boosted the financial services sector. This skewed investment towards sectors that serviced the consumption boom (retailing, distribution, personal financial services and credit, equity release) based on fictitious credit. This increased the mass and share of profits going to interest-bearing capital at the expense of profit-producing capital that creates internationally tradable commodities. In turn, this aggravated the crowding out effects of the housing sector borrowing requirement on productive investment, and discouraged regional labour mobility from areas of high unemployment to areas of labour shortage.

This illustrates on a national scale the more general observation of Martin and Gardiner about the multi-scalar effects of what I describe as neo-liberal finance-dominated accumulation:

The financial crisis revealed the boom for what it was, a form of development that was highly unbalanced: on a global level, between creditor and debtor nations (especially China and the USA respectively); within the Eurozone, between the strong core members such as Germany and France, and the weaker peripheral members such as Spain, Italy and Portugal; and within countries, between consumption and investment, between services and production, between state revenues and spending, between rich and poor, and, spatially, between different cities and regions. For while the 'long boom' between the early 1990s and 2007 may have lifted most regions and cities, it lifted some much more than others. Indeed, in some instances (the UK is a particularly prominent case) it reinforced regional inequalities (Martin \& Gardiner, 2018, p. 25).

\section{Brexit}

[The Brexit vote] was a singular event that is but one symptom of a continuing organic crisis of the British state and society and a stimulus for further struggles over the future of the United Kingdom and its place in Europe and the wider world (Jessop, 2017, p. 133).

This claim illustrates Gramsci's observation that a crisis is 'a process and not an event (Gramsci, 1995, p. 219). Its course and outcomes depend on how crisis symptoms are construed and managed. Europe and the European Union have long been a neuralgic point of division inside the Conservative Party and within the establishment more widely. In this sense, the decision to run a referendum on Brexit and its result were symptoms of an organic crisis. The referendum result did not resolve this crisis but reproduced it in new guises.

This can be seen in the failure of the British state, the ruling party, business interests, or organized labour to develop a coherent negotiating position in the following two years. It was six months after the referendum vote, on 29 March 2017, that the official letter required under Article 50 of the Lisbon Treaty to formally notify the European Commission of the UK government's intention to withdraw from the European Union. The delay was not spent working out a negotiating position or preparing an exit strategy in the case 
of no deal. In contrast, the European Union prepared a tough negotiating position. Negotiations began on 19 June 2017, 11 days after the 2017 General Election, which, far from giving the Prime Minister, Theresa May, a strong mandate, saw her losing her majority and dependent for a majority on the support of Northern Ireland's hard-line Democratic Unionist Party MPs, which gave them a veto over decisions on the border issue and future relations with the Irish Republic. Negotiations focused first on the 'divorce' bill before post-Brexit arrangements could be discussed. After several unplanned delays, a fudged agreement on the conditions for discussing the final settlement and post-Brexit transition arrangements was reached in late December 2017. Some issues were agreed, others left ambiguous, and some postponed. The latter included the border arrangements between Northern Ireland and the Irish Republic. Discussions on this and other issues began on 19 March 2018. The Cabinet committee charged with preparing the UK's negotiating position failed to reach agreement in time for the June summit of the European Union. A negotiating position was eventually agreed at a full Cabinet meeting on 6 July 2018, based on fudging the government's redlines on sovereignty, trade, and free movement and 'cherry-picking' on customs arrangement for agricultural and manufactured goods while leaving services outside any future deal. Whether the negotiating position holds within the government and ruling party before negotiations begin was unclear as this article was finalized on 7 July 2018. It could well do so because time is short to secure a deal before the dead line and no deal would mean there is no transition period - only a cliff-edge exit for which the government has not prepared. Even before this, growing realization of the difficulties of exiting from a 45-year entanglement with the European Union led to a contested agreement on a 21-month-long 'transitional' arrangement during which little will change substantively. Accordingly, Brexit proper is due to happen eventually on 1 January 2021, which is four and a half years after the referendum.

The weakness of a neoliberalized state apparatus has much to do with these delays. The state, as argued above, has been unable to act in an effective dirigiste, corporatist, liberal (or, more recently, neo-liberal) manner. Muddling through on a week-by-week basis while trying different grand strategies is its modus operandi. The stark divisions within parliamentary parties, national parties, and the electorate on the issue of Brexit and its most suitable form have reinforced this. And, surprisingly, given how significant Brexit is for the prospects of business and finance, it has taken two years for major commercial, industrial, and financial interests to articulate their positions in public. In part this reflects the fact that the Balkanization of the UK economy means that there is no significant national or comprador bourgeoisie that could benefit from Brexit and that the multiple international linkages of capital also block a coherent stance. So, there is no collective voice of capital (apart from the plea for certainty) and it has taken almost two years for individual capitals, fractions, and sectors to begin to voice worries and begin special pleading. But this situation also reflects the toxic nature of pro-Brexit tabloid media reaction to any gain-saying of the 'will of the people', whether this gain-saying comes from the Supreme Court, the House of Lords, Cabinet members, Members of Parliament, respected think tanks, or other significant forces. This reflects the continuing hegemonic crisis in the power bloc, representational crises rooted in partisan dealignment, electoral volatility, and disaffection with politics, and crises of authority and legitimacy.

In addition, cumulative budget cuts and staff reductions in the civil service over 40 years have left the state without qualified staff to prepare serious impact reports on the 
implications of Brexit on specific sectors, regions, generations, and the wider society; likewise, it lacks sufficient personnel who understand the diplomatic, legal, financial and economic aspects of trade negotiations, which have long been delegated to the European Union, to present a clear Brexit strategy. These deficits matter because the European Union has a strong rechtsstaatlich (constitutional and legal) orientation such that negotiations occur within the framework of the Treaties, legal rules, and conventions and overseen by the Court of Justice of the European Union, which is charged with ensuring equal implementation and enforcement of the treaties, laws, and rules. Maintaining the legal integrity of the European Union, even as its range of activities expands in new directions following the Eurozone crisis, the rise of internal divisions on migration, and the Trumpinduced, multi-faceted fractures in transatlantic unity, is crucial to its overall operation. The redlines set out in the government's initial negotiating position, notably regaining national sovereignty over laws, trade, and borders, threaten the legal identity of the European Union and limit possible Brexit outcomes. The British common law tradition has encouraged collective misapprehension on this point within parts of the British establishment and the pro-Brexit media, leading them to interpret Brussels' redlines as a rejection of compromise and attempt to 'punish' Britain for its temerity in voting to leave the European Union. Similar effects stem from the commitment to a nineteenth-century notion of national sovereignty in an increasingly integrated planet earth, world economy, and world of states that has recognized the need for - always contested - forms of governance to address supranational threats, challenges and crises.

Much of what passes for 'negotiation' on the UK side ... has involved a desire to retain the benefits of EU membership while shrugging off the status and responsibilities of membership. But when Mrs May appeals for 'a comprehensive system of mutual recognition' she is going still further. She is not asking for something that applies within the EU. She is asking for something that even EU Member States do not expect of each other. A 'comprehensive system of mutual recognition' is not found within the EU. Mrs May is asking that the UK be treated better than a Member State of the EU (Weatherill, 2018).

Yet these complexities are ignored because, as Wren-Lewis notes, 'Brexiteers believed they owned the referendum victory, and so acted as if they had the right to decide what Brexit means' (2018). Following the referendum, the British public have been regularly informed that 'Brexit means Brexit', that the government is committed to securing the 'best Brexit for the whole of the United Kingdom' and that 'No deal would be better than a bad deal'. These anodyne assertions are a smokescreen for cluelessness on how to deliver Brexit and, even after agreement on the government's negotiating position in July 2018, there is no certainty that it will prove acceptable to the EU negotiators or the remaining member states. Some commentators are speculating that Brexiteers hope that they will reject it, so that a 'clean Brexit' on World Trade Organization terms would eventually ensue.

Apart from the Department for Exiting the European Union (DExEU), no department had Brexit as its top priority or a major priority in its Single Department Plan for 2017/18 financial year. This situation remains for 2018/19. Even departments whose briefs will be most impacted by Brexit have not integrated it into their priorities but mention it as a consideration relevant to their priorities (Lloyd, 2018; more generally on lack of preparation, see Owen, Lloyd, \& Rutter, 2018). This is compounded by the paralysis of the Conservative Cabinet, parliamentary party, and grass-roots members, who are overwhelmingly elderly 
Brexit supporters. As the deadline for an agreement approaches, the room for manoeuvre is shrinking (e.g. the issue of the Irish border, the problems of reconciling national autonomy with the complementary but different requirements of continued membership of the customs union (which bans internal tariffs) and single market (which includes freedom of movement as well as freedom in the flow of goods), the possibility of separate deals on goods and services, the special status of London as an international financial centre for international financial capital, fisheries and agriculture, and so on). There is also miscalculation about the speed and ease with which new free trade deals can be negotiated with other governments, each of which has its own negotiating agenda. A significant irony in the present situation is that, by and large, the advocates of hard Brexit lack expertise in many of these topics, thanks to a naïve understanding of national sovereignty that is inappropriate to a world of interdependent states and thanks also to a blind Ricardian faith in the virtues of free trade among nations premised on comparative advantage that is inappropriate to a world of just-in-time commodity chains and finance-dominated accumulation. Conversely, those who have expertise in these matters are largely opposed to Brexit in general and cannot, in any case, design a form of Brexit that is impossible in principle or, if it were feasible, cannot be delivered within the current time-frame (e.g. registration of aliens, customs software, trade negotiations). The point has been reached when there are not enough funds, staff, political clarity, or time to exit the EU on schedule, even on a 'clean Brexit', no deal basis, following World Trade Organization rules. This helps to explain the steady series of concessions to the EU negotiating redlines, such as the divorce bill, the granting of EU citizens full rights during the transition period, the 'backstop' plan for keeping Northern Ireland in the customs union and single market in the absence of any other arrangement acceptable to Ireland and the European Union more generally, no new trade deals to be implemented before 2020, and so on.

Ian Dunt's conclusions on the Brexit process shortly after the referendum remain valid:

Britain's government is approaching Brexit ineptly, misjudging its opponent, underestimating the challenges and prioritising its short-term political interests over the long-term interests of the country. Our ministers have thrown away their leverage and failed to neutralise the advantages held by the EU. Through a mixture of ignorance and ideological frenzy, they are driving Britain towards a hard, chaotic Brexit (Dunt, 2016, pp. 154-50).

\section{Uneven development after Brexit}

Whatever the outcome of the Article 50 negotiations, Brexit will not reverse the historical legacies of uneven development. On the contrary, it is likely to worsen the situation for the Northern peripheral regions, where there was strong support for Brexit, relative to the City and the UK's southern core (Lavery, 2017, p. 39; see also Clarke, Goodwin, \& Whitely, 2017). This can be seen in four areas: the trade effects of Brexit, the loss of EU structural funds and other regional support, and the regional economic impact of likely economic regress and falling government revenues. Overall this will damage Brexit-supporting regions and Brexit voters more than Remain-supporting regions.

First, the export base of London and the rest of the South East is far more internationalized than that of other UK regions and therefore less exposed to the impact of declining trade with the EU (Los, McCann, Springford, \& Thissen, 2017). This reflects the economic and financial base of the South compared with the rest of the UK. Between 1993 and 2007, 
output in banking and finance increased by 180 per cent whilst manufacturing (upon which Northern economies remained more heavily reliant) saw increases of only 11 per cent (Martin, 2010, p. 37). London is the only city region to have exceeded pre-crisis levels of per capita output and is the only region to have increased employment in the financial sector since 2009 (Lavery, 2017). One consequence is that, whereas EU exports account for 7 per cent of London's gross product, other regions, notably in the North and South-West, depend far more heavily on EU markets and, indeed, the level of local dependence increased between 2000 and 2010 in 34 of the UK's Nuts-2 regions (Los et al., 2017, p. 789). In addition, as major manufacturing firms are now emphasizing publicly, their commodity chains are integrated with the EU and will be disrupted by tariffs, new customs frictions, and sterling devaluation. For example, the Society of Motor Manufacturers and Traders (SSMT) reports that 20-50 percent of components in the automotive sector are sourced from the EU (SSMT, 2014, p. 6). In contrast, London and the South East have seen decreasing reliance on EU demand in this period. The Brexiteers response that components could be sourced more cheaply from the world market and that competitive pressure would force EU suppliers to reduce prices ignores the complexities of trade deals and supply chains. Recognition of this risk seems to have informed the compromise negotiating position reached on 8 July 2018, which aims for a customs partnership in agricultural and manufactured goods.

Second, there will be a severe post-Brexit loss after of EU grants supporting UK institutions, cities and regions, and economic activities and replacing them through UK funding will diminish the much-vaunted 'Brexit dividend'. Regarding uneven development, EU structural funds have gone disproportionately to 'less developed' and 'transition' regions, such as the South West, Wales, Yorkshire and Humber, the North East, and North West. ${ }^{4}$ For example, seven of the ten local economic partnerships that received the most structural funding were located in the North; the South was home to all of the ten partnerships that received the lowest level of funding (Hunt, Lavery, Vittery, \& Berry, 2016, pp. 67). ${ }^{5}$ Local authorities in rural areas also predict massive detriment as unaffordable homes, poor connectivity, skills gaps and health inequalities will threatening their future success and prosperity (Carroll, 2018).

Third, if there is no Brexit dividend, which is the most likely outcome according to calculations about the impact of all four possible Brexit scenarios from hard Brexit through a bespoke deal to the softest of Brexits (Global Future, 2018), this will limit the funds available to the UK government to cushion the impact in peripheral regions, cities, and towns and to assist their regeneration. The research by Jonathan Portes and associates for the Global Future think-tank found that even a bespoke deal, the government's preferred option, would have a net negative fiscal impact of about $£ 40$ bn a year. Government reports indicate similar results.

Fourth, recent research by the Institute for Public Policy Research (Lloyd, 2018) and the Oliver Wyman consultancy (2018) have established that a hard Brexit would hit the cost of living for those outside London more because of their lower household incomes and the composition of their purchases of goods and services, which are more exposed to tariff increases (e.g. meat and dairy products) or prices increases due to devaluation (oil and gas). Overall, gains from importing 150 goods and services from agreeing free trade deals with all other countries in the world market will not compensate for the increased cost of imports from the European Union under any of the four Brexit scenarios (Oliver Wyman, 2018). 


\section{Conclusions}

There is no pure case of neoliberalism, nor of the four types identified in my taxonomy. The British case is closest to a principled neoliberal regime shift and is an important case for the proposed periodization of such shifts into seven stages to date. Nonetheless, every case also has special features in general and in each stage. This is clearly so for the United Kingdom. The background to the post-war crisis is Britain's 'flawed Fordism', the dominance of finance capital economically and in the power bloc (Establishment) even during the heyday of Fordism, and a state that lacked the capacities to engage in effective corporatist, dirigiste, or liberal intervention in pursuit of a coherent accumulation strategy or state project. This provided the distinctive context for the principled neoliberal regime shift, pragmatically prefigured in the dying days of the 1975-79 Labour Government, that achieved its 'point of no return' or take-off moment in 1978. Subsequent stages of neoliberalization aggravated rather than reversing the flawed development of the British space economy, worsening its uneven development, and creating the conditions for the financial crisis. The latter in turn intensified the organic crisis of the state even as it provided an opportunity to strengthen the dominance of financial capital and extend neoliberalization. Yet austerity, uneven development, and disillusion also prepared the ground for the referendum vote for Brexit, the consequences of which include a continuation of the organic crisis of the British state, further uneven development, and Brexceptionalism. It seems as if the Brexit referendum was the hinge between 'a failed state' and 'a state intent on failure' (cf. Younge, 2016). ${ }^{6}$ For an incapable government presiding over an ineffective state that has failed to plan for no deal and is more fearful of pro-Brexit media barons wielding power without responsibility than the sotto voce opposition of business and finance has sought to reclaim sovereignty without being able to able to exercise it effectively, let alone in the public good.

\section{Notes}

1. This taxonomy draws on Jessop (2016b, 2018).

2. Witness the 2012 Olympic Games, the Cross-Rail project in London, and the third Heathrow runway.

3. Cf. Gramsci (1971, p. 261).

4. Projects supported by the European Regional Development Fund created 44,331 jobs in Wales in the 2007-2013 funding round; other job creation figures were 20,149 (Yorkshire and Humberside), 20,602 (North East), and 29,795 (North West) (Hunt et al., 2016, p. 7).

5. There are 39 LEPS in total in England.

6. I owe the wonderful quotation from Gary Younge to MacLeod and Jones (2018). Younge actually described Britain as 'cutting the figure not so much of a failed state as a state intent on failure'. The quotation was too good not to use again but I amended the quotation and his extended coda to better reflect the argument developed in this article.

\section{Acknowledgment}

This article was written during tenure of fellowship at Cardiff University in the WISERD Civil Society Programme funded by the Economic and Social Research Council [award: ES/L009099/ 1]. My analysis benefitted from discussions with Martin Jones. I am also grateful to Phil Cooke for his patience as I finished the article and for his insightful feedback. 


\section{Disclosure Statement}

No potential conflict of interest was reported by the author.

\section{Funding}

This article was written during tenure of fellowship at Cardiff University in the WISERD Civil Society Programme funded by the Economic and Social Research Council [grant number ES/ L009099/1].

\section{ORCID}

Bob Jessop (1) http://orcid.org/0000-0001-8134-3926

\section{References}

Black, W. K. (2014, May 27). Posing as hyper-rationality: OMB’s assault on effective regulation. New Economic Perspectives.

Brenner, N. (2004). New state spaces. Oxford: Oxford University Press.

Bruff, I. (2014). The rise of authoritarian neoliberalism. Rethinking Marxism, 26(11), 113-129. doi:10.1080/08935696.2013.843250

Carroll, L. (2018, July 4). Brexit to have greatest negative impact on regions outside London. The Guardian. Retrieved from https://www.theguardian.com/politics/2018/jul/04/brexit-greatestnegative-impact-regions-outside-london

Clarke, H., Goodwin, M., \& Whitely, P. (2017). Brexit: Why Britain voted to leave the European Union. Cambridge: Cambridge University Press.

Davis, E. P., \& Latter, A. R. (1989). London as an international financial centre. Bank of England Quarterly Bulletin, 29(11), 516-528.

Dunt, I. (2016). Brexit. What the hell happens now? London: Canbury Press.

Global Future. (2018). Too high a price: The cost of Brexit, what the public thinks. London: Global Future. Retrieved from https://ourglobalfuture.com/wp-content/ .../04/GlobalFuture-Too_ high_a_price.pdf

Gramsci, A. (1971). Selections from the prison notebooks. London: Lawrence \& Wishart.

Gramsci, A. (1995). Further selections from the prison notebooks. London: Lawrence \& Wishart.

Hadjimichalis, C. (1987). Uneven development and regionalism: State, territory and class in Southern Europe. London: Croom Helm.

Hadjimichalis, C. (2018). Crisis spaces: Structures, struggles and solidarity in Southern Europe. London: Routledge.

Hudson, R. (2003). European integration and new forms of uneven development but not the end of territorially distinctive capitalisms in Europe. European Urban and Regional Studies, 10(1), 4967. doi: $10.1177 / \mathrm{a} 032539$

Hunt, T., Lavery, S., Vittery, W., \& Berry, C. (2016). UK regions and European structural and investment funds. Sheffield, UK: Sheffield Political Economy Research Institute. SPERI British Political Economy Brief No. 24. Retrieved from http://speri.dept.shef.ac.uk/wp-content/uploads/2016/05/ Brief24-UK-regions-and-European-structural-and-investment-funds.pdf

Ingham, G. (1984). Capitalism divided? The City and industry in British social development. Basingstoke: Macmillan.

Jessop, B. (1980). The transformation of the state in postwar Britain. In R. Scase (Ed.), The state in Western Europe (pp. 23-94). London: Croom Helm.

Jessop, B. (1992). From social democracy to Thatcherism: Twenty-five years of British politics. In N. Abercrombie, \& A. Warde (Eds.), Social change in contemporary Britain (pp. 45-68). Cambridge: Polity. 
Jessop, B. (2016a). Territory, politics, governance and multispatial metagovernance. Territory, Politics, Governance, 4(1), 8-32. doi:10.1080/21622671.2015.1123173

Jessop, B. (2016b). The heartlands of neoliberalism and the rise of the austerity state. In S. Springer, K. Birch \& J. MacLeavy (Eds.), The handbook of neoliberalism (pp. 410-421). London: Routledge. Jessop, B. (2017). The organic crisis of the British state: Putting Brexit in its place. Globalizations, 14 (2), 133-141. doi:10.1080/14747731.2016.1228783

Jessop, B. (2018). Neoliberalism and workfare: Schumpeterian or Ricardian? In D. Cahill, M. Konings, M. Cooper \& D. Primrose (Eds.), SAGE handbook of neoliberalism (pp. 347-358). London: SAGE.

Jessop, B., Bonnett, K., Bromley, S., \& Ling, T. (1988). Thatcherism: A tale of two nations. Cambridge: Polity.

Lavery, S. (2017). Will Brexit deepen the UK's 'North-South' divide? In S. Lavery, L. Quaglia \& C. Dannreuther (Eds.), The political economy of Brexit and the UK's national business model. Sheffield, UK: SPERI Paper No. 41. Retrieved from http://speri.dept.shef.ac.uk/wp-content/ uploads/2017/05/SPERI-Paper-41-The-Political-Economy-of-Brexit-and-the-UK-s-NationalBusiness-Model.pdf

Lloyd, L. (2018). A missed chance to reassure that Whitehall has Brexit covered. London: Institute for Government. Retrieved from https://www.instituteforgovernment.org.uk/blog/missed-chancereassure-whitehall-has-brexit-covered

Los, B., McCann, P., Springford, J., \& Thissen, M. (2017). The mismatch between local voting and the local economic consequences of Brexit. Regional Studies, 51(5), 786-799. doi:10.1080/ 00343404.2017 .1287350

MacLeod, G., \& Jones, M. (2018). Explaining 'Brexit Capital': Regional inequality and the austerity state. Unpublished paper.

Martin, R. (1988). The political economy of Britain's north-south divide. Transactions of the Institute of British Geographers, 13(4), 389-418. doi:10.2307/622738

Martin, R. (2010). Uneven regional growth: The geographies of boom and bust under new labour. In N. M. Coe \& A. Jones (Eds.), The economic geography of the UK (pp. 29-46). London: Sage.

Martin, R., \& Gardiner, B. (2018). Reviving the "northern powerhouse" and spatially rebalancing the British economy: The scale of the challenge. In C. Berry \& A. Giovannini (Eds.), Developing England's North: The political economy of the northern powerhouse (pp. 23-58). Basingstoke: Palgrave-Macmillan.

Martin, R., Pike, A., Tyler, P., \& Gardiner, B. (2015). Spatially rebalancing the UK economy: Towards a new policy model? Falmer, UK: Regional Studies Association.

Oliver Wyman (2018). Costs up, prices up. Brexit's impact on consumer business and their customers. London: Oliver Wyman. Retrieved from http://www.oliverwyman.com/our-expertise/insights/ 2018/jul/brexit-costsup--prices-up.html

Owen, J., Lloyd, L., \& Rutter, J. (2018). Preparing Brexit. How ready is Whitehall? London: Institute for Government.

Peck, J., \& Theodore, N. (2012). Reanimating neoliberalism: Process geographies of neoliberalization. Social Anthropology, 20(2), 177-185. doi:10.1111/j.1469-8676.2012.00194.x

Peck, J., \& Tickell, A. (1992). Local modes of social regulation? Regulation theory, Thatcherism and uneven development. Geoforum; Journal of Physical, Human, and Regional Geosciences, 23(3), 347-363.

Piketty, T. (2014). Capitalism in the $21^{\text {st }}$ century. Cambridge, MA: Harvard University Press.

Rasmus, J. (2010). Epic recession. London: Pluto Press.

Shonfield, A. (1965). Modern capitalism: The changing balance between public and private power. Oxford: Oxford University Press.

SSMT (2014). The UK automotive industry and the EU, KPMG report. Retrieved from https://www. smmt.co.uk/wp-content/uploads/sites/2/SMMT-KPMG-EU-Report.pdf

Weatherill, S. (2018). What mutual recognition really entails: analysis of the Prime Minister's Mansion House speech. Retrieved from http://eulawanalysis.blogspot.com/2018/03/whatmutual-recognition-really-entails.html 
Weber, M. (2009) General economic history. Brunswick, NJ: Transaction Books <1923>

Wren-Lewis, S. (2018). The complete failure of the Brexit project. https://mainlymacro.blogspot. com/2018/04/the-complete-failure-of-brexit-project.html

Younge, G. (2016, June 30). Brexit: A disaster decades in the making. The Guardian. https://www. theguardian.com/politics/2016/jun/30/brexit-disaster-decades-in-the-making 